\title{
STUDI PENGGUNAAN KLOSET KERING PEMISAH URIN DAN TINJA UNTUK PENINGKATAN PENGELOLAAN LIMBAH URIN DAN TINJA PADA PERMUKIMAN DI SURABAYA
}

\author{
Arlini Dyah Radityaningrum \\ Jurusan Teknik Lingkungan Institut Teknologi Adhi Tama Surabaya, Surabaya, Indonesia \\ Email:dyah@itats.ac.id
}

\begin{abstract}
ABSTRAK
Pengelolaan limbah domestik black water (urin dan tinja) pada permukiman dapat dilakukan menggunakan sistem setempat (on-site), yang terdiri dari kloset dan tangki septik yang dilengkapi dengan sistem resapan. Teknologi kloset yang digunakan dalam pengolahan sistem setempat umumnya belum memisahkan antara limbah urin dan tinja. Sistem setempat dengan teknologi kloset tanpa pemisah urin dan tinja masih menimbulkan dampak negatif terhadap lingkungan, berupa pencemaran air permukaan dan air tanah. Selain itu kondisi teknis tangki septik yang tidak kedap berpotensi meresapnya limbah urin dan tinja ke dalam tanah. Peningkatan pengelolaan urin dan tinja dapat dilakukan dengan memperbaiki kondisi teknis fasilitas pengelolaannya, baik kloset maupun tangki septik dan resapan, sehingga urin dan tinja dapat digunakan kembali dan tidak dibuang ke lingkungan.'Teknologi Kloset Kering Pemisah Urin dan Tinja`dapat diterapkan untuk memisahkan urin dan tinja pada sumbernya sehingga potensi kandungan nutrien dalam urin dan tinja dapat dimanfaatkan secara optimal. Penelitian ini bertujuan untuk menguji kelayakan penggunaan kloset kering ditinjau dari aspek lingkungan dengan metode penilaian daur hidup. Batasan yang digunakan adalah recovery dari nutrien dan konsumsi energi. Skenario yang dianalisa adalah (1) Pengelolaan limbah urin dan tinja tanpa kloset kering pemisah urin dan tinja dengan tangki septik dan resapan, (2) Pengelolaan limbah urin dan tinja dengan kloset kering pemisah urin dan tinja dengan bak pengumpul urin dan tangki septik. Hasil penelitian menunjukkan bahwa skenario pengelolaan limbah urin dan tinja menggunakan toilet kering pemisah urin dan tinja menghasilkan dampak lingkungan paling minimal dengan recovery nutrien sebesar $0,0485 \mathrm{~kg}$ nitrogen/rumah tangga/hari; $0,009 \mathrm{~kg}$ pospor/rumah tangga/hari; 0,0165 kg kalium/rumah tangga/hari dan konsumsi energi sebesar 4179,35 kiloJoule/rumah tangga/hari.
\end{abstract}

Kata kunci: sistem setempat, kloset kering, metode penilaian daur hidup, recovery nutrien, konsumsi energi

\section{PENDAHULUAN}

Perkembangan permukiman di Kota Surabaya merupakan dampak urbanisasi yang berpotensi menimbulkan pencemaran, satu di antaranya adalah pencemaran air permukaan dan air tanah. Hal ini disebabkan oleh kondisi eksisting pengelolaan limbah domestik urin dan tinja yang tidak memadai. Menurut Donald (2011), data dari Bappeko menunjukkan bahwa sejumlah $87,5 \%$ dari penduduk di permukiman Kota Surabaya telah menggunakan kloset dan tangki septik dilengkapi dengan resapan sebagai fasilitas pengelolaan limbah urin dan tinja. Namun, dari 87,5\% tersebut diperkirakan hanya sekitar 56,6\% menerapkan fasilitas yang memadai dalam pengelolaan limbah urin dan tinja, sedangkan sekitar 30,9\% masih belum memiliki fasilitas yang memadai (Donald, 2011). Fasilitas kloset yang umum digunakan di permukiman adalah kloset tanpa pemisah urin dan tinja. Kondisi teknis kloset ini dan konstruksi tangki septik yang tidak kedap berpotensi menimbulkan pencemaran pada air permukaan dan air tanah.

Perbaikan fasilitas pengelolaan limbah urin dan tinja di Kota Surabaya merupakan upaya urgen yang harus segera dilakukan untuk meningkatkan kualitas air permukaan dan air tanah di Kota Surabaya. Ecological sanitation (ecosan) merupakan konsep pengelolaan sanitasi dengan mempertimbangkan aspek ekologi, sehingga penerapan ecosan memiliki unsur keberlanjutan dan berdampak positif terhadap lingkungan (Langergraber \& Muellegger, 2005). Satu teknologi yang menggunakan konsep ecosan adalah kloset kering pemisah urin dan tinja. Penerapan kloset kering pemisah urin menggunakan konsep recovery, reuse, recycle, baik air maupun nutrien dari urin dan tinja. Pemisahan urin dan tinja pada sumber limbah dilanjutkan dengan pengolahan urin dan tinja secara sederhana dilakukan dengan tujuan supaya urin dan tinja yang telah diolah dapat digunakan kembali secara optimal, sehingga limbah urin dan tinja tidak dibuang ke lingkungan. Recycle air dan nutrien hasil pengolahan limbah urin dan tinja mampu menutup siklus air dan nutrien di lingkungan, sehingga 
mengurangi potensi pencemaran pada air permukaan dan air tanah. Kandungan nutrien dalam urin dan tinja yang telah diolah dapat dimanfaatkan sebagai pupuk tanaman dan penambah nutrisi tanah. Selain itu, kegiatan recycle nutrien tersebut dapat menghindari proses eutrofikasi pada air permukaan (Larsen et al., 2007).

Penerapan kloset kering pemisah urin dan tinja dilengkapi dengan pengolahan sederhana terhadap urin dan tinja merupakan alternatif solusi terhadap permasalahan pencemaran air permukaan dan air tanah akibat limbah domestik. Penggunaan kloset kering harus dilengkapi dengan kondisi tangki septik yang sesuai standar, yaitu dengan konstruksi kedap. Kelayakan penerapan ecosan menggunakan teknologi kloset kering dalam pengelolaan limbah urin dan tinja di permukiman dengan sistem setempat dapat diuji melalui metode penilaian daur hidup. Penelitian ini bertujuan menilai kelayakan penggunaan teknologi kloset kering dalam pengelolaan limbah urin dan tinja ditinjau dari aspek lingkungan, yaitu recovery nutrien dan konsumsi energi.

\section{TINJAUAN PUSTAKA}

\section{Kloset kering pemisah urin dan tinja}

Kloset kering pemisah urin dan tinja merupakan penerapan konsep ecosan, yang menyatakan bahwa limbah urin dan tinja merupakan sumber daya yang dapat diolah dan dimanfaatkan kembali. Limbah urin dan tinja yang dikelola dengan teknologi kloset tanpa pemisah urin dan tinja berpotensi terhadap pencemaran nutrien di badan air maupun air tanah. Pencegahan pencemaran nutrien dari limbah urin dan tinja dapat dilakukan dengan cara menutup siklus nutrien dari limbah urin dan tinja melalui pengolahan dan pemanfaatan kembali nutrien dari limbah urin dan tinja sebagai pupuk dan penambah nutrisi tanah (Zeeman dan Lettinga, 1999). Hal ini juga dapat mengurangi penggunaan sumber daya tak terbarukan dan konsumsi energi yang digunakan dalam produksi pupuk buatan. Penggunaan kloset kering pemisah urin dan tinja merupakan alternatif yang efektif untuk menutup siklus nutrien dan siklus air untuk digunakan kembali, seperti ditunjukkan dalam Gambar 1 . Konsentrasi nutrien yang digunakan kembali untuk pupuk maupun penambah kesuburan tanah mampu ditingkatkan dengan pemisahan limbah urin dan tinja menggunakan kloset kering. Teknologi kloset kering pemisah urin dan tinja ini dapat berupa kloset jongkok maupun kloset duduk yang dilengkapi dengan sekat pemisah untuk urin dan tinja pada kloset. Selain itu, kloset dilengkapi dengan socket transisi yang menghubungkan urin ke perpipaan urin menuju bak penampung dan bak pengolahan urin serta menghubungkan tinja ke perpipaan menu tangki septik. Detail ilustrasi kloset kering tersebut dapat dilihat dalam Gambar 2.

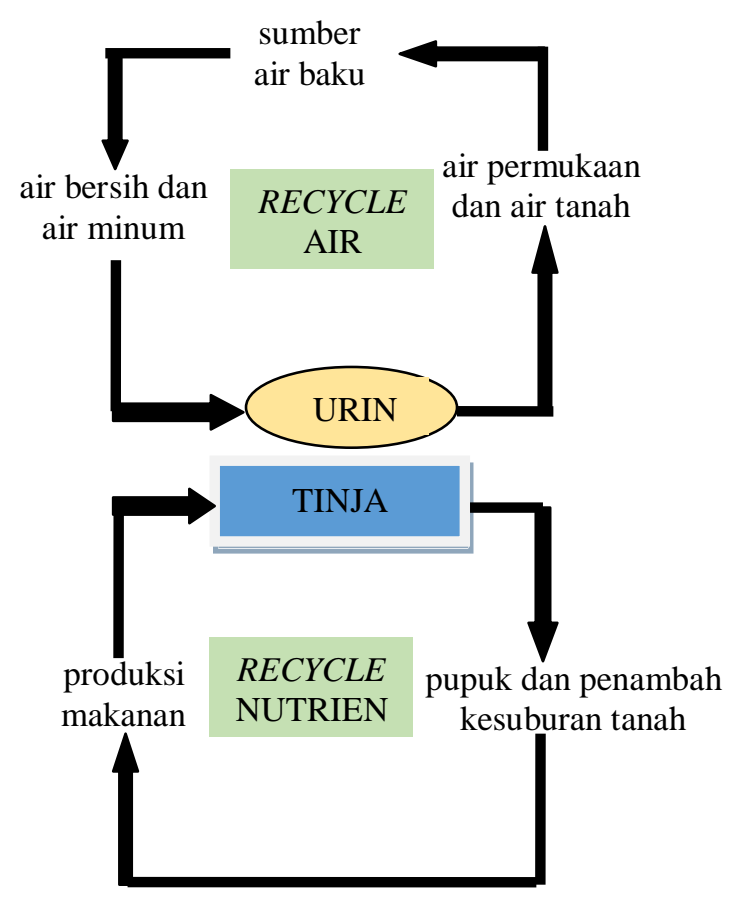

Sumber: Langergrabber dan Muellegger (2005)

Gambar 1. Siklus tertutup air dan nutrien 


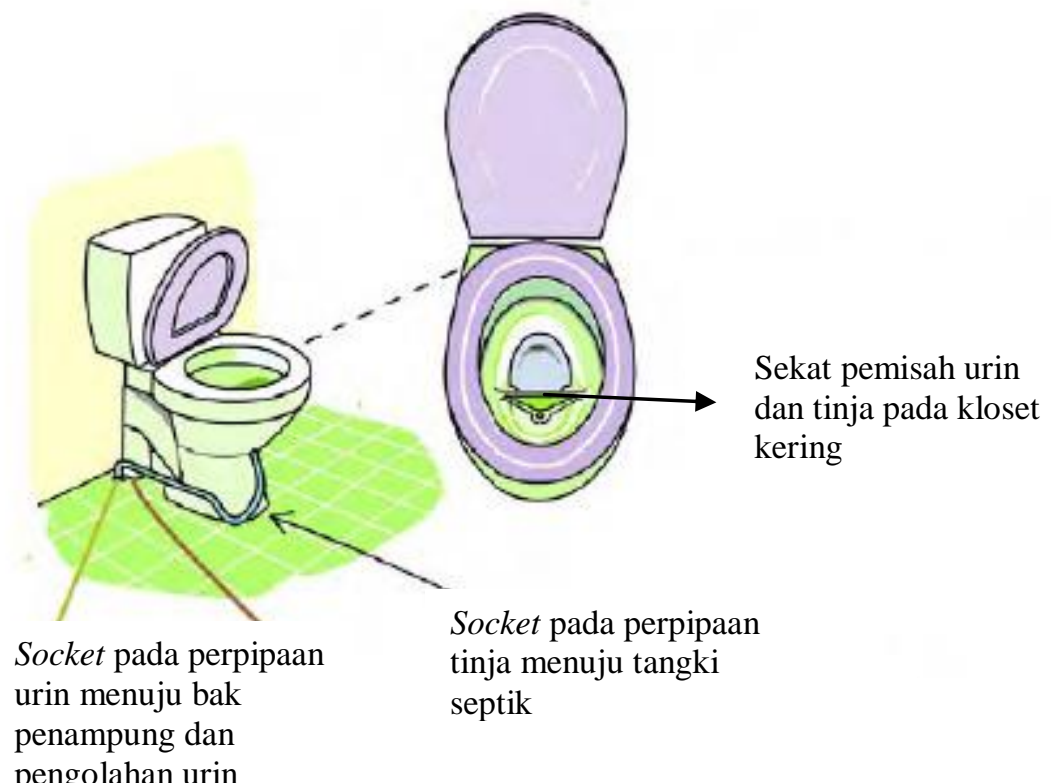

Sumber: Kvarnstrom et al. (2006)

Gambar 2. Kloset kering duduk pemisah urin dan tinja

\section{Recovery, reuse, recycle air dan nutrien}

Proses recovery air dan nutrien dalam urin dan tinja sebelum dimanfaatkan kembali (reuse) dilakukan untuk meningkatkan kualitas air dan nutrien dalam urin dan tinja. Reuse air dan nutrien bertujuan untuk menutup siklus air dan nutrien. Recovery air dan nutrien dalam urin dan tinja menghasilkan kualitas air dan nutrien yang optimal apabila urin dan tinja tidak tercampur. Menurut Magid et al. (2006) menyatakan bahwa limbah urin yang dihasilkan dari kloset tanpa pemisah urin dan tinja berpotensi terkontaminasi oleh bakteri patogen yang terkandung dalam limbah tinja. Selain itu limbah tinja yang tidak dipisahkan dari urin berpotensi memiliki kadar air yang besar sehingga kandungan bahan organik dalam tinja tidak optimal untuk digunakan sebagai pupuk organik untuk kegiatan agrikultural (Skjelhaugen, 1999). Oleh sebab itu untuk pemanfaatan yang optimal, diperlukan pengolahan terpisah dan pemisahan urin dan tinja pada sumbernya karena perbedaan karakteristik antara urin dan tinja. Pengolahan urin yang sudah dipisahkan pada kloset kering pemisah urin dan tinja dilakukan dengan penyimpanan sederhana pada bak pengumpul. Periode penyimpanan tergantung pada jenis tanaman yang digunakan untuk reuse urin tersebut, dengan periode minimal 6 bulan (Malisie, 2008). Reuse urin direkomendasikan untuk diaplikasikan pada tanaman non pangan dan tanaman pangan non umbi-umbian (Langergraber \& Muellegger, 2005). Recovery tinja dilakukan melalui proses composting. Tinja kering dari kloset kering pemisah urin dan tinja dikomposkan dengan bahan adsorben seperti abu, potongan kertas untuk penghilangan bakteri pathogen (Lamichhane, 2007). Menurut Nakagawa et al. (2006), kompos jadi dari tinja dapat digunakan kembali untuk pupuk tanaman

\section{Makronutrien dalam urin dan tinja}

Kandungan nutrien dalam urin dan tinja yang telah dipisahkan terdiri dari Nitrogen (N), Pospor (P), Potassium atau Kalium (K), dapat dilihat dalam Tabel 1. Selain itu, menurut Jonsson dan Vinneras (2007), karakteristik utama urin meliputi nilai pH 4,8 - 7, kandungan nitrogen dalam bentuk urea sebesar $75 \%$ - 90\%.

Tabel 1. Kandungan makronutrien urin dan tinja dalam limbah domestik dari toilet kering pemisah urin dan tinja

\begin{tabular}{|l|c|c|c|}
\hline Makronutrien & Beban nutrien (kg/orang/tahun) & $\begin{array}{c}\text { Urin } \\
500 \text { 1/orang/tahun }\end{array}$ & $\begin{array}{c}\text { Tinja } \\
50 \text { 1/orang/tahun }\end{array}$ \\
\hline Nitrogen & 4 to 5 & $87 \%$ & $10 \%$ \\
Pospor & 0.75 to 1 & $50 \%$ & $40 \%$ \\
Kalium & 1.5 to 2 & $54 \%$ & $12 \%$ \\
\hline
\end{tabular}

Sumber: Langergraber and Muellegger (2005) 


\section{Penilaian daur hidup}

Metode penilaian daur hidup merupakan asesmen terhadap penerapan skenario sistem baru maupun teknologi baru yang ditinjau dari sudut pandang lingkungan, dimana evaluasi dilakukan secara menyeluruh terhadap dampak lingkungan yang ditimbulkan pada seluruh proses dalam daur hidup (Machado et al., 2007 dan Benetto et al., 2009). Tahapan dalam penilaian daur hidup meliputi (i). penentuan peta daur hidup dan batasan analisa; (ii). penentuan unit fungsional; (iii). penentuan data analisa; (iv). penilaian dampak lingkungan; (v). interpretasi. Rekomendasi terhadap penerapan teknologi atau sistem baru diberikan berdasarkan interpretasi dari penilaian daur hidup.

\section{METODE}

Penelitian ini menggunakan metode penilaian daur hidup untuk menguji kelayakan penerapan teknologi kloset kering pemisah urin dan tinja ditinjau dari aspek lingkungan. Diagram alir penelitian dapat dilihat dalam Gambar 3. Penilaian daur hidup penerapan kloset kering pemisah urin dan tinja dalam penelitian ini dilakukan terhadap tahap ekstraksi sumber daya untuk produksi pupuk, produksi pupuk, transpor pupuk, penggunaan teknologi kloset kering pemisah urin dan tinja, proses recovery, recycle, reuse urin dan tinja. Skenario yang dikembangkan dalam penilaian daur hidup adalah (1) Pengelolaan limbah urin dan tinja tanpa kloset kering pemisah urin dan tinja dengan tangki septik dan resapan, (2) Pengelolaan limbah urin dan tinja dengan kloset kering pemisah urin dan tinja dengan bak pengumpul urin dan tangki septik. Batasan penilaian yang digunakan adalah aspek recovery nutrien dan konsumsi energi.

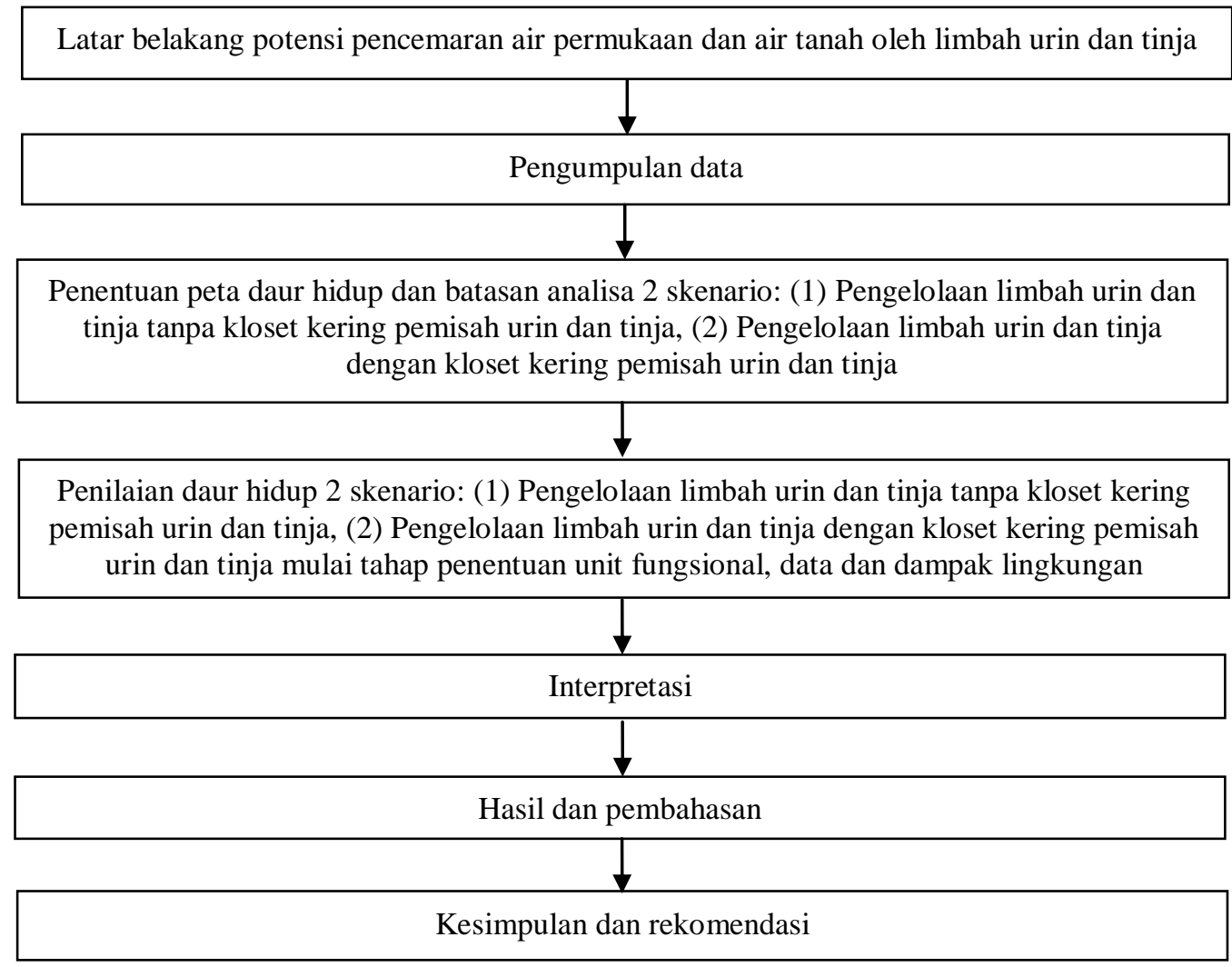

Gambar 3. Diagram alir penelitian

\section{HASIL DAN PEMBAHASAN}

\section{Peta daur hidup dan batasan}

Penilaian daur hidup penerapan toilet kering pemisah urin dan tinja menggunakan peta daur hidup untuk masing-masing skenario yang dianalisa, seperti dalam Gambar 4 dan Gambar 5. Berdasarkan peta penilaian daur hidup dapat dianalisa input, proses dan output pada setiap kegiatan dalam daur hidup yang berpotensi menimbulkan dampak lingkungan. Batasan yang digunakan dalam penilaian daur hidup adalah recovery nutrien dan konsumsi energi. Berdasarkan peta daur hidup pada Gambar 4, skenario ke-1, sistem pengelolaan urin dan tinja tanpa kloset kering pemisah urin dan tinja menunjukkan bahwa siklus air dan nutrien yang dihasilkan dari 
sistem pengelolaan pada skenario ke-1 masih bersifat terbuka. Urin dan tinja yang telah diolah serta kandungan nutriennya dibuang ke badan air penerima, dan berpotensi terhadap pencemaran nutrien. Air dan nutrien yang dihasilkan dari pengelolaan urin dan tinja dapat digunakan kembali setelah dilakukan proses recovery, sehingga dapat dikembalikan dalam siklus air dan nutrien. Recycle air dan nutrien dapat menutup siklus air dan nutrien sehingga air dan nutrien dari urin dan tinja yang terolah tidak dibuang ke lingkungan. Hal ini dapat mengurangi potensi pencemaran air oleh urin dan tinja. Selain itu reuse air dan nutrien dari urin dan tinja yang telah terolah mampu menggantikan penggunaan pupuk buatan. Kegiatan recovery, recycle, reuse urin dan tinja yang telah terolah dapat mengurangi konsumsi energi yang digunakan dalam proses produksi pupuk buatan dan transportasi pupuk buatan. Menurut Gellings dan Parmenter (2004), konsumsi energi yang dibutuhkan dalam proses produksi, pengepakan, transportasi dan penggunaan pupuk buatan Nitrogen, Pospor, Kalium ditunjukkan dalam Tabel 2.
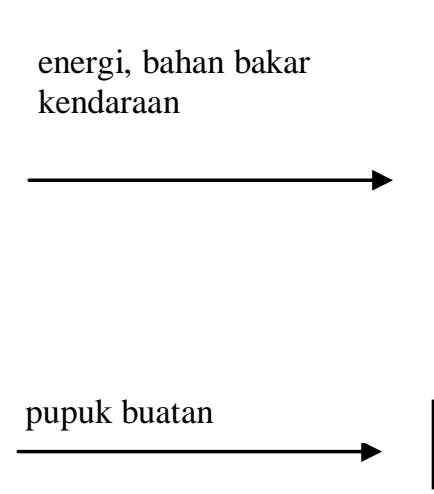

energi, bahan bakar kendaraan

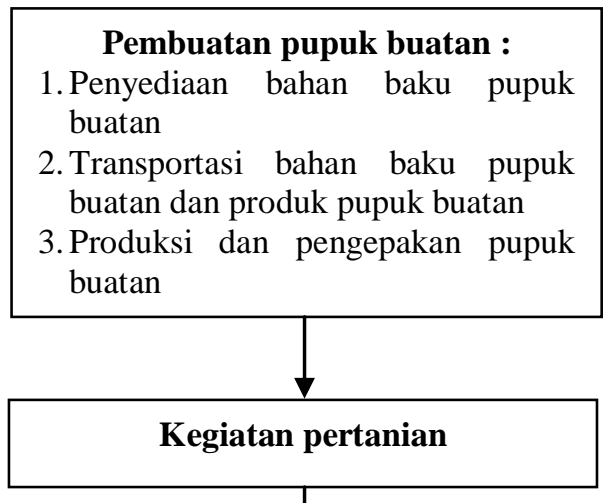

Penyediaan buatan

Transportasi bahan baku pupuk buatan dan produk pupuk buatan

Produksi dan pengepakan pupuk buatan
$\mathrm{CO}_{2}, \mathrm{~N}_{2} \mathrm{O}$, pupuk buatan

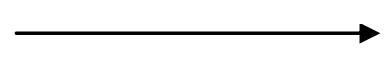

makanan (nutrien: $\mathrm{N}, \mathrm{P}, \mathrm{K}$ )

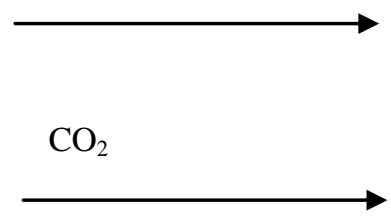

Transportasi pangan ke manusia urin dan tinja (nutrien: $\mathrm{N}, \mathrm{P}, \mathrm{K}$ ), energi, bahan bakar kendaraan

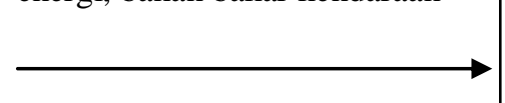

\section{Skenario ke-1: Pengelolaan limbah urin dan tinja tanpa kloset kering pemisah urin dan tinja dengan tangki septik dan resapan}

1. Kloset tanpa pemisah urin dan tinja

2. Tangki septik dan resapan

3. Transportasi ke Instalasi Pengolahan Lumpur Tinja (IPLT) urin dan tinja terolah (nutrien: $\mathrm{N}, \mathrm{P}, \mathrm{K}$ ),

$\mathrm{CO}_{2}$

urin dan tinja yang sudah diolah (nutrien: $\mathrm{N}, \mathrm{P}, \mathrm{K}$ )

Sumber: Hasil analisa (2017)

\section{Pembuangan ke badan air penerima}

Gambar 4. Peta daur hidup sistem pengelolaan urin dan tinja tanpa kloset kering pemisah urin dan tinja 
Tabel 2. Konsumsi energi pada proses produksi, pengepakan, transportasi dan penggunaan pupuk buatan Nitrogen,

\begin{tabular}{|l|c|c|c|}
\hline \multirow{2}{*}{\multicolumn{1}{|c|}{ Kegiatan }} & \multicolumn{3}{|c|}{ Pospor, Kalium } \\
\cline { 2 - 4 } & Nitrogen & Pospor & Kalium \\
\hline Produksi & 69,530 & 7700 & 6400 \\
Pengepakan & 2600 & 2600 & 1800 \\
Transportasi & 4500 & 5700 & 4600 \\
Penggunaan & 1600 & 1,500 & 1000 \\
\hline Total & 78,230 & 17,500 & 13,800 \\
\hline
\end{tabular}

Sumber: Gellings dan Parmenter (2004)

Pupuk organik dari urin dan tinja yang telah diolah

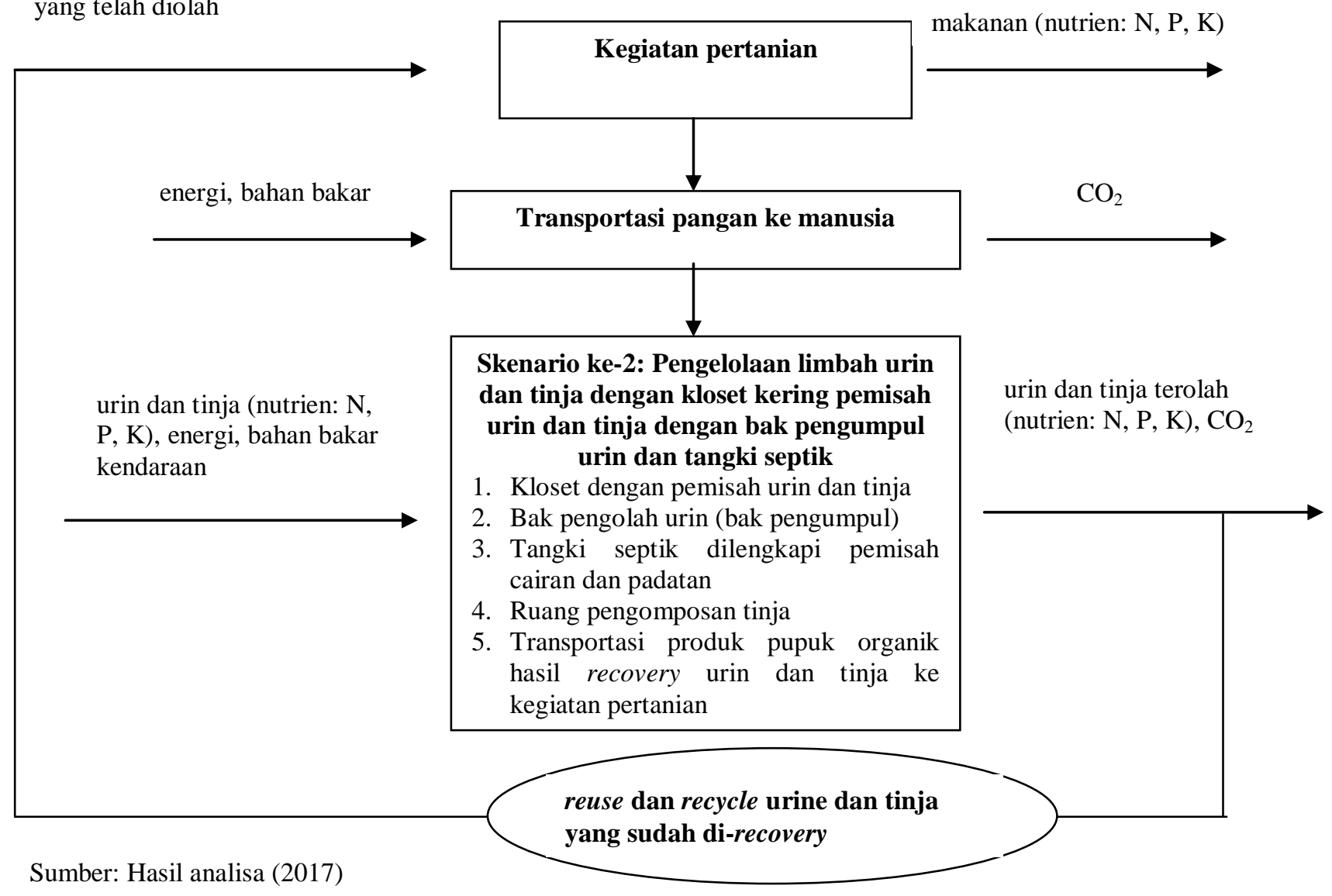

Gambar 5. Peta daur hidup sistem pengelolaan urin dan tinja menggunakan kloset kering pemisah urin dan tinja

Batasan yang digunakan dalam penilaian daur hidup pada penelitian ini adalah recovery nutrien dan konsumsi energi yang terlibat dalam daur hidup masing-masing skenario. $\mathrm{CO}_{2}$ dalam peta daur hidup diabaikan dalam analisa penelitian ini, karena $\mathrm{CO}_{2}$ dapat digunakan kembali dalam proses produksi pupuk. Penggunaan toilet kering pemisah urin dan tinja dapat menutup siklus air dan nutrien, karena air dan nutrien dari pemisahan urin dan tinja dapat diolah secara optimal dan dikembalikan ke daur hidupnya untuk digunakan kembali sebagai pupuk organik pengganti pupuk kimia. Oleh sebab itu, kegiatan produksi, pengepakan, transportasi dan penerapan pupuk merupakan satu komponen dalam peta daur hidup pada masing-masing skenario.

\section{Unit fungsional}

Unit fungsional dalam penilaian daur hidup pada penelitian ini adalah pengelolaan urin dan tinja yang dihasilkan permukiman per hari secara aman bagi lingkungan dan manusia.the safe excreta disposal for a household 
generated per day. Asumsi yang digunakan dalam skenario penerapan teknologi kloset kering pemisah urin dan tinja adalah jumlah penghuni per rumah tangga adalah 5 jiwa. Makronutrien yang dianalisa dalam penilaian daur hidup ini adalah Nitrogen, Pospor, Kalium dengan persentase kandungan masing-masing dalam urin dan tinja tercantum dalam Tabel 2.1.

\section{Penilaian recovery nutrien}

Recovery nutrien yang dihasilkan per rumah tangga per hari dari penggunaan toilet kering pemisah urin dan tinja dapat diperkirakan berdasarkan Tabel 1, dengan asumsi dan analisa sebagai berikut:

- Asumsi jumlah penghuni per rumah tangga: 5 jiwa

- Asumsi jumlah hari dalam 1 tahun: 365 hari

- Nutrien Nitrogen yang terkandung dalam urin: $87 \%$

- Nutrien Pospor yang terkandung dalam urin: $50 \%$

- Nutrien Kalium yang terkandung dalam urin: $54 \%$

- Nutrien Nitrogen yang terkandung dalam tinja: $10 \%$

- Nutrien Pospor yang terkandung dalam tinja: $40 \%$

- Nutrien Kalium yang terkandung dalam tinja: $12 \%$

- Volume urin per orang: 500 liter/tahun = 1,37 liter/hari

- Volume tinja per orang: 50 liter/tahun = 0,14 liter/hari

- Beban produksi nutrien nitrogen dari urin dan tinja per orang: $4 \mathrm{~kg} / \mathrm{tahun}=0,01 \mathrm{~kg} / \mathrm{hari}$

- Beban produksi nutrien pospor dari urin dan tinja per orang: $0,75 \mathrm{~kg} / \mathrm{tahun}=0,002 \mathrm{~kg} / \mathrm{hari}$

- Beban produksi nutrien kalium dari urin dan tinja per orang: $1,8 \mathrm{~kg} / \mathrm{tahun}=0,005 \mathrm{~kg} / \mathrm{hari}$

Berdasarkan analisa di atas dapat diperkirakan bahwa jumlah nutrien nitrogen, pospor dan kalium dari urin dan tinja yang dapat direcovery untuk kemudian digunakan kembali dapat dilihat dalam Tabel 3.

Tabel 3. Recovery makronutrien urin dan tinja dalam limbah domestik dari toilet kering pemisah urin dan tinja

\begin{tabular}{|l|c|c|c|c|}
\hline \multirow{2}{*}{ Makronutrien } & \multicolumn{2}{|c|}{ Recovery nutrien (kg/rumah tangga/hari) } & \multicolumn{2}{c|}{ Recovery nutrien (liter/rumah tangga/hari) } \\
\cline { 2 - 5 } & Urin & Tinja & Urin & Tinja \\
\hline Nitrogen & 0,0435 & 0,0050 & 5,96 & 0,07 \\
Phosphorus & 0,0050 & 0,0040 & 3,43 & 0,28 \\
Kalium & 0,0135 & 0,0030 & 3,70 & 0,08 \\
\hline
\end{tabular}

Sumber: Hasil analisa (2017)

\section{Penilaian konsumsi energi}

Kegiatan recovery nutrien (nitrogen, pospor, kalium) yang memungkinkan nutrien tersebut untuk kembali ke daur hidupnya (recycle) dan dapat digunakan kembali (reuse) sebagai pupuk organik pengganti pupuk buatan berdampak terhadap pengurangan konsumsi energi dalam proses produksi pupuk buatan. Berdasarkan jumlah recovery makronutrien dalam penerapan teknologi toilet kering pemisah urin dan tinja, maka dapat diperkirakan pengurangan konsumsi energi dari proses produksi, pengepakan, transportasi dan penggunaan pupuk buatan. Besarnya konsumsi energi yang dapat dikurangi dengan penggunaan toilet kering pemisah urin dan tinja diestimasikan berdasarkan Tabel 2 dan Tabel 3, dengan hasil analisa sebagai berikut:

Tabel 4. Pengurangan konsumsi energi pada proses produksi, pengepakan, transportasi dan penggunaan pupuk buatan Nitrogen, Pospor, Kalium dari penerapan teknologi kloset pemisah urin dan tinja pada tiap rumah tangga

\begin{tabular}{|l|c|c|c|}
\hline \multirow{2}{*}{ Kegiatan } & \multicolumn{3}{|c|}{ Konsumsi energi $(\mathrm{kJ})$} \\
\cline { 2 - 4 } & Nitrogen & Pospor & Kalium \\
\hline Produksi & 3372,2 & 69,3 & 105,6 \\
Pengepakan & 126,1 & 23,4 & 29,7 \\
Transportasi & 218,25 & 51,3 & 75,9 \\
Penggunaan & 77,6 & 13,5 & 16,5 \\
\hline Total & 3794,15 & 157,5 & 227,7 \\
\hline Total & & 4179,35 & \\
\hline
\end{tabular}

Sumber: Hasil analisa (2017) 
Berdasarkan Tabel 4, kontribusi tiap rumah tangga terhadap pengurangan konsumsi energi per hari dengan penggunaan toilet kering pemisah urin dan tinja adalah sebesar 4179,35 kJoule.

\section{Interpretasi}

Penggunaan teknologi toilet kering pemisah urin dan tinja dalam pengelolaan urin dan tinja pada rumah tangga mampu me-recovery makronutrien Nitrogen, Pospor dan Kalium untuk dijadikan pupuk organik, serta menghemat energi yang digunakan dalam kegiatan produksi, pengepakan, transportasi dan penggunaan pupuk buatan. Pengolahan sederhana urin dan tinja pada rumah tangga setelah dipisahkan di toilet pemisah urin dan tinja meliputi bak pengumpul sekaligus sebagai tangki penyimpanan urin serta tangki septik dan ruang pengomposan untuk tinja. Teknologi kloset pemisah urin dan tinja digunakan pada tiap rumah tangga dengan asumsi jumlah penghuni 5 orang. Urin yang telah dipisahkan dialirkan melalui perpipaan menuju bak pengumpul dan disimpan di ruang penyimpanan selama minimal 6 bulan untuk dapat digunakan sebagai penambah kesuburan tanah dan tanaman. Tinja kering yang telah dipisahkan kemudian dialirkan ke tangki septik. Proses pengomposan tinja kering dilakukan setelah disedot dari tangki septik.

\section{KESIMPULAN}

Penggunaan teknologi kloset kering pemisah urin dan tinja pada permukiman dapat meningkatkan pengelolaan limbah urin dan tinja sehingga meningkatkan kualitas lingkungan air permukaan dan air tanah. Hal ini disebabkan penggunaan kloset kering mampu me-recovery unsur makronutrien Nitrogen, Pospor dan Kalium dalam urin dan tinja sehingga dapat dikembalikan ke daur hidupnya dan digunakan kembali sebagai pupuk organik. Urin dan tinja yang digunakan sebagai pengganti pupuk buatan tidak dibuang secara langsung ke badan air penerima dan tidak berpotensi terhadap pencemaran air permukaan dan air tanah. Recovery nutrien yang dihasilkan dari penerapan teknologi kloset kering pemisah urin dan tinja adalah sebesar $0,0485 \mathrm{~kg}$ nitrogen/rumah tangga/hari; 0,009 kg pospor/rumah tangga/hari; 0,0165 kg kalium/rumah tangga/hari. Selain itu proses recovery, recycle dan reuse urin dan tinja dapat mengurangi konsumsi energi yang digunakan dalam proses produksi, pengepakan, transportasi dan penggunaan pupuk buatan sebesar 4179,35 kiloJoule/rumah tangga/hari. Berdasarkan analisa tersebut maka dapat disimpulkan bahwa untuk skenario ke-2, yaitu pengelolaan limbah urin dan tinja dengan kloset kering pemisah urin dan tinja dengan bak pengumpul urin dan tangki septik dapat direkomendasikan untuk peningkatan pengelolaan limbah urin dan tinja pada permukiman.

\section{DAFTAR PUSTAKA (DAN PENULISAN PUSTAKA)}

Benetto, E., Nguyen, D., Lohmann, T., Schmitt, B. \& Schosseler, P. (2009) 'Life cycle assessment of ecological sanitation system for small-scale wastewater treatment'. Science of the Total Environment, Vol. 407, hal. 1506-1516.

Donald, M.M. (2011) 'Wastewater investment masterplan package I Surabaya`

Gellings, C. W. \& Parmenter, K. E. (2004) `Energy efficiency in fertilizer production and use. retrieved from www.eolss.net/ebooks/Sample\%20Chapters/C08/E3-18-04-03.pdf-, accessed 14 may 2009.

Lamichhane, K. M. (2007) `On-site sanitation: a viable alternative to modern wastewater treatment plants`. Water Science and Technology, Vol. 55, hal. 433-440.

Langergraber, G. \& Muellegger, E. (2005) `Ecological Sanitation--a way to solve global sanitation problems? Environment International, Vol. 31, hal. 433-444.

Larsen, T. A., Maurer, M., Udert, K. M. \& Lienert, J. (2007) `Nutient cycles and resource management: implications for the choice of wastewater treatment technology`. Water Science \& Technology, Vol. 56, hal. 229-237.

Machado, A. P., Urbano, L., Britto, A. G., Janknecht, P., Salas, J. J. \& Noguiera, R. (2007) 'Life cycle assessment of wastewater treatment options for small and decentralized communities`. Water Science \& Technology, Vol. 56, hal. 15-22.

Magid, J., Eilersen, A. M., Wrisberg, S. \& Henze, M. (2006) 'Possibilities and barriers for recirculation of nutrients and organic matter from urban to rural areas: A technical theoretical framework applied to the medium-sized town Hiller, Denmark`. Ecological Engineering, Vol. 28, hal. 44-54.

Malisie, A. F. (2008) 'Sustainability assessment on sanitation systems for low income urban areas in Indonesia` Environmental Engineering. Hamburg, German, The Hamburg University of Technology (TUHH).

Nakagawa, N., Otaki, M., Miura, S., Hamasuna, H. \& Ishizaki, K. (2006) `Field survey of a sustainable sanitation system in a residential house`. Journal of Environmental Sciences, Vol. 18, hal. 1088-1093.

Skjelhaugen, O. J. (1999) 'Closed system for local reuse of blackwater and food waste integrated with agriculture`. Water Science and Technology, Vol. 39, hal. 161-168.

Zeeman, G. \& Lettinga, G. (1999) `The role of anaerobic digestion of domestic sewage in closing the water and nutrient cycle at community level'. $W a$ 